University of Nebraska - Lincoln

DigitalCommons@University of Nebraska - Lincoln

Publications from USDA-ARS / UNL Faculty

U.S. Department of Agriculture: Agricultural

Research Service, Lincoln, Nebraska

$1-1-2008$

\title{
Biotinyl-methyl 4-(amidomethyl)benzoate is a competitive inhibitor of human biotinidase
}

\author{
Keyna Kobza \\ University of Nebraska-Lincoln \\ Kittichai Chaiseeda \\ University of Nebraska-Lincoln \\ Gautam Sarath \\ University of Nebraska-Lincoln, Gautam.sarath@ars.usda.gov \\ James M. Takacs \\ University of Nebraska-Lincoln, jtakacs1@unl.edu \\ Janos Zempleni \\ University of Nebraska-Lincoln, jzempleni2@unl.edu
}

Follow this and additional works at: https://digitalcommons.unl.edu/usdaarsfacpub

Part of the Agricultural Science Commons

Kobza, Keyna; Chaiseeda, Kittichai; Sarath, Gautam; Takacs, James M.; and Zempleni, Janos, "Biotinylmethyl 4-(amidomethyl)benzoate is a competitive inhibitor of human biotinidase" (2008). Publications from USDA-ARS / UNL Faculty. 203.

https://digitalcommons.unl.edu/usdaarsfacpub/203

This Article is brought to you for free and open access by the U.S. Department of Agriculture: Agricultural Research Service, Lincoln, Nebraska at DigitalCommons@University of Nebraska - Lincoln. It has been accepted for inclusion in Publications from USDA-ARS / UNL Faculty by an authorized administrator of DigitalCommons@University of Nebraska - Lincoln. 


\title{
Biotinyl-methyl 4-(amidomethyl)benzoate is a competitive inhibitor of human biotinidase
}

\author{
Keyna A. Kobza ${ }^{\mathrm{a}}$, Kittichai Chaiseeda ${ }^{\mathrm{b}}$, Gautam Sarath ${ }^{\mathrm{c}}$, \\ James M. Takacs ${ }^{\mathrm{b}}$, Janos Zempleni ${ }^{\mathrm{a}, *}$ \\ ${ }^{a}$ Department of Nutrition and Health Sciences, University of Nebraska-Lincoln, Lincoln, NE 68583-0806, USA \\ ${ }^{\mathrm{b}}$ Department of Chemistry, University of Nebraska-Lincoln, Lincoln, NE 68583-0806, USA \\ ${ }^{\mathrm{c}}$ USDA-ARS and Department of Entomology, University of Nebraska at Lincoln, Lincoln, NE 68583-0806, USA \\ Received 1 June 2007; received in revised form 15 October 2007; accepted 8 November 2007
}

\begin{abstract}
Posttranslational modification of histones by biotinylation can be catalyzed by both biotinidase (BTD) and holocarboxylase synthetase. Biotinylation of histones is an important epigenetic mechanism to regulate gene expression, DNA repair, and chromatin remodeling. The role of BTD in histone biotinylation is somewhat ambiguous, given that BTD also catalyzes removal of the biotin tag from histones. Here, we sought to develop BTD inhibitors for future studies of the role of BTD in altering chromatin structure. We adopted an existing colorimetric BTD assay for use in a novel 96-well plate format to permit high-throughput screening of potential inhibitors. Biotin analogs were chemically synthesized and tested for their ability to inhibit human BTD. Seven of these compounds inhibited BTD by $26-80 \%$. Biotinyl-methyl 4-(amidomethyl)benzoate had the largest effect on BTD, causing an $80 \%$ inhibition at $1 \mathrm{mM}$ concentration. Enzyme kinetics studies were conducted to determine $V_{\max }, K_{\mathrm{m}}$ and $K_{\mathrm{i}}$ for the seven inhibitors; kinetics were consistent with the hypothesis that biotinyl-methyl 4-(amidomethyl)benzoate and the other compounds acted by competitive inhibition of BTD. Finally, biotinyl-methyl 4-(amidomethyl) benzoate did not affect biotin transport in human cells, suggesting specificity in regard to biotin-related processes.
\end{abstract}

(C) 2008 Published by Elsevier Inc.

Keywords: Biotinidase; Biotinyl-methyl 4-amidomethyl benzoate; Histones; Inhibitors

\section{Introduction}

Mammals contain two biotin-metabolizing enzymes, namely, holocarboxylase synthetase (HCS) and biotinidase (BTD). HCS is a cytoplasmic, mitochondrial, and nuclear protein [1-3], whereas BTD is predominantly secreted into serum $[4,5]$ but can also be found in the cell nucleus [2,4]. HCS catalyzes the covalent binding of biotin to a specific lysine residue in apocarboxylases to produce holocarboxylases [6]. The classic function of BTD is to recycle biotin by hydrolyzing the amide bond between biotin and lysine residues (biocytin) in breakdown products of holocarboxylases [7].

Abbreviations: BTD, biotinidase; DMSO, dimethyl sulfoxide; HCS, holocarboxylase synthetase; MCD, multiple carboxylase deficiency; PABA, para-aminobenzoic acid.

* Corresponding author. Tel.: +1 402472 3270; fax: +1 4024721587.

E-mail address: jzempleni2@unl.edu (J. Zempleni).
Recently, it was proposed that both BTD and HCS also catalyze the biotinylation of $\varepsilon$-amino groups in specific lysine residues in histones [1,8-11]. Posttranslational modifications of histones have distinct functions in chromatin metabolism. For example, trimethylation of K4 in histone $\mathrm{H} 3$ is associated with transcriptional activation of genes, whereas dimethylation of $\mathrm{K} 9$ in histone $\mathrm{H} 3$ is associated with transcriptional silencing $[12,13]$.

All five major classes of histones are targets for biotinylation in human cells [10]. While the physiological roles of histone biotinylation are under investigation, there is increasing evidence that histone biotinylation plays a role in DNA repair [14], gene silencing and heterochromatin structures in human cells [15] and stress resistance and life span in Drosophila $[16,17]$. Biotinylation of histones is mediated by both HCS $[1,16]$ and BTD [8], but evidence has been provided that HCS is the dominant histone-biotinyl ligase [16]. 
Table 1

Inhibitors of BTD

\begin{tabular}{lll}
\hline Inhibitors & $\begin{array}{l}\% \\
\text { Inhibition }^{\mathrm{a}}\end{array}$ \\
\hline Biotinyl anilide & $55 \pm 0.1$ &
\end{tabular}

Biotinyl allylamide $\quad 37 \pm 0.09$<smiles>C=CCNC(=O)CCCC[As]1SCC2NC(=O)NC21</smiles>

Biotinyl $26 \pm 0.05$

$N$-methylanilide<smiles>CN(C(=O)CCCC[C@H]1SCC2NC(=O)NC21)c1ccccc1</smiles><smiles>C=C(OC)c1ccc(CNC(=O)CCCC[As]2SCC3NC(=O)NC32)cc1</smiles>

Biotinyl $\quad 40 \pm 0.05$

2-amido-pyridine<smiles>C=C/C=C(\N=C)NC(=O)CCCCC1CC2NC(=O)NC12</smiles>

Biotinylation of histones is a reversible modification. Ballard et al. [18] suggested that debiotinylation of histones might be mediated by BTD. The regulation of BTD to favor debiotinylation of histones over biotinylation of histones by the same enzyme is unknown. A number of variables may regulate the catalytic activity of BTD. First, the availability of substrate might favor either biotinylation or debiotinylation of histones. For example, locally high concentrations of biocytin might shift the reaction equilibrium toward biotinylation of histones $[8,19]$. Second, proteins may interact with BTD at the chromatin level, favoring either biotinylation or debiotinylation of histones. Third, three alternatively spliced variants of BTD have been identified [20]. Theoretically, these variants may have unique functions with regard to histone biotinylation. Fourth, BTD possesses six glycosylation sites [21,22]; glycosylation of BTD might affect its cellular location [23].

Our long-term goal is to identify the roles of BTD in biotinylation and debiotinylation of histones. As a first step toward this goal, we generated a first generation of synthetic inhibitors of BTD, and we developed a 96-well plate assay for high-throughput screening of putative BTD inhibitors.

Previous studies have proposed using biotin, di-isopropylfluorophosphate and thiol reagents such as $p$-chloromercuribenzoate as inhibitors of BTD [4]. These compounds are of limited use for the following two reasons. First, diisopropylfluorophosphate and $p$-chloromercuribenzoate are general inhibitors of enzymes as opposed to being specific inhibitors of BTD. Second, simultaneous inhibition of BTD in both cytoplasm and nucleus make it impossible to link potential effects of low BTD activity to altered histone debiotinylation in the nucleus as opposed to impaired biotin recycling in the cytoplasm. The studies presented here lay the groundwork for the development of second-generation inhibitors that can be targeted directly to the nucleus to interfere with histone debiotinylation without affecting cytoplasmic events.

\section{Materials and methods}

\subsection{BTD purification}

Human plasma, which is known to contain high levels of BTD activity [4], served as a source of BTD in this study. Approximately $150 \mathrm{ml}$ of human blood was collected through venipuncture into heparinized containers. This study was approved by the Institutional Review Board for Human Subjects at the University of Nebraska-Lincoln. Plasma was separated from blood cells by centrifugation $(870 \times g$ for $30 \mathrm{~min})$. Previous studies indicated that BTD precipitates between $30 \%$ and $50 \%$ saturation with ammonium sulfate [24]. Thus, for all experiments described here, plasma BTD was precipitated using 30-50\% saturation with ammonium sulfate. Precipitated proteins, usually from $10 \mathrm{ml}$ of plasma, were resuspended in $1.5 \mathrm{ml}$ of potassium phosphate buffer $(0.1 \mathrm{M}, \mathrm{pH} 6)$ and dialyzed for $24-36 \mathrm{~h}$ against three changes

a Percent inhibition compared with inhibitor-free control after 2 of incubation of BTD+Inhibitor+Substrate. Values are means \pm S.D. ( $n=6 ; P<.05$ compared with inhibitor-free control). 


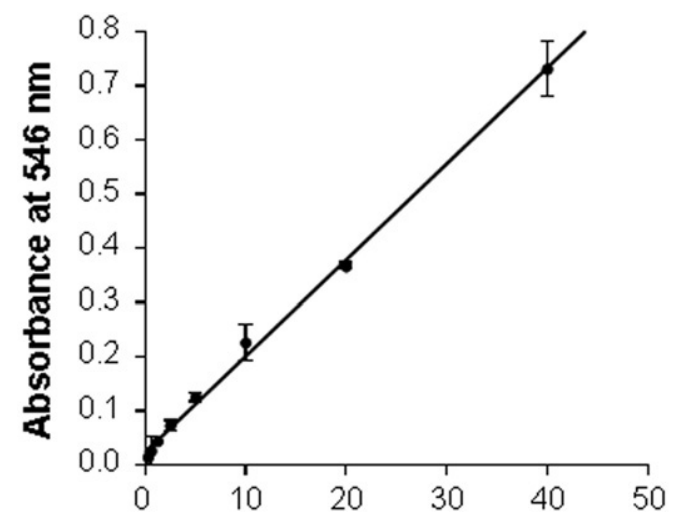

4-Aminobenzoic acid (nmoles/well)

Fig. 1. Standard curve for colorimetric quantification of PABA. Absorbance of derivatives of PABA was measured at $546 \mathrm{~nm}$. The S.D.'s are too small to be visible at low amounts of PABA $(y=0.0013 x+0.021 ; r=.998)$.

of $1 \mathrm{~L}$ of potassium phosphate buffer at $4^{\circ} \mathrm{C}$. Dialyzed samples were subdivided into 1-ml aliquots and stored at $-20^{\circ} \mathrm{C}$. Please note that these crude preparations of BTD might contain proteins that affect analysis of $V_{\max }, K_{\mathrm{m}}$, and $K_{\mathrm{i}}$. Individual aliquots were thawed and used as needed for BTD assays as described below. The amount of protein was quantified by using the Nanodrop 1000 spectrophotometer (Wilmington, DE). Plasma BTD activity is known to vary by about $25 \%$ among healthy individuals [25], explaining the sample-to-sample variation described below.

\subsection{BTD inhibitors}

Putative inhibitors of BTD were synthesized by conjugating biotin to various allylamines using carbodiimide as the coupling reagent. Briefly, equimolar amounts $(0.21 \mathrm{mmol})$ of D-biotin $(50 \mathrm{mg}), N$-(3-dimethylaminopropyl)- $N^{\prime}$-ethylcarbodiimide hydrochloride $(39 \mathrm{mg}), 4$-(dimethylamino)pyridine $(25 \mathrm{mg})$ and allylamine derivatives (Table 1) were dissolved in $5 \mathrm{ml}$ of $\mathrm{N}, \mathrm{N}$-dimethylformamide in an 8 -ml vial. The solution was stirred under nitrogen atmosphere overnight. After the reaction was complete (checked by thin-layer chromatography and stained with iodine or phosphomolybdic acid solution), DMF ( $N, N$-dimethylformamide) was evaporated under vacuum. The crude product was column chromatographed on silica gel (Silica gel 60, 40-63 $\mu \mathrm{m}$, EMD Chemical; Gibbstown, NJ). The column was first washed with $50 \mathrm{ml}$ dichloromethane and the product eluted with $150 \mathrm{ml}$ dichloromethane/methanol (10:1, by volume). Solvents were removed by vacuum drying to obtain a white solid powder product at a $40-90 \%$ yield. ${ }^{1} \mathrm{H}$ and ${ }^{13} \mathrm{NMR}$ was used to verify the identity of the product.

\subsection{BTD assay}

BTD activity was measured as the rate of hydrolysis of $N$ biotinyl-4-aminobenzoic acid to release 4-aminobenzoic acid (PABA). The latter was quantified using $N$-1-naphthylethylenediamine dihydrochloride as described by Knappe et al. [26] and Backman-Gullers et al. [27] and modified by Nilsson and Ronge [28]. These protocols were adapted for microtiter plates as follows. In a 96-well microtiter plate, $500 \mu \mathrm{g}$ of partially purified BTD from plasma and $12 \mu \mathrm{l}$ of $10 \mathrm{mM}$ putative BTD inhibitors $(120 \mathrm{nmol} / \mathrm{well} ; 1.0 \mathrm{mM}$ final concentration) were mixed with $88 \mu 1$ of $54 \mathrm{mM}$ sodium phosphate buffer ( $\mathrm{pH} 6.0$ ), containing $1.08 \mathrm{mM}$ disodium EDTA and $4.3 \mathrm{mM}$ cysteamine hydrochloride (prepared fresh); samples were preincubated at $37^{\circ} \mathrm{C}$ for $60 \mathrm{~min}$. Then, $10 \mu \mathrm{l}$ of $6 \mathrm{mM} \mathrm{N-(+)-biotinyl-PABA}(60 \mathrm{nmol} /$ well; $0.5 \mathrm{mM}$ final concentration) was added to each well and plates were incubated for $120 \mathrm{~min}$ at $37^{\circ} \mathrm{C}$. Reactions were stopped by adding $30 \mu \mathrm{l}$ of $6 \mathrm{M}$ hydrochloric acid and the following compounds were added at 3-min intervals at room temperature: $55 \mu \mathrm{l}$ water, $15 \mu \mathrm{l}$ of $14.5 \mathrm{mM}$ sodium nitrite (prepared fresh), $15 \mu \mathrm{l}$ of $43.8 \mathrm{mM}$ ammonium sulfamate, and $15 \mu \mathrm{l}$ of $3.86 \mathrm{mM} \mathrm{N}$-1-naphtylethylenediamine dihydrochloride. Incubation was continued for $10 \mathrm{~min}$. Precipitated proteins were removed by centrifugation $(1260 \times g$ for $10 \mathrm{~min}$ ) and the supernatant was transferred to a new plate and the absorbance was measured at $546 \mathrm{~nm}$. Previous studies suggested that BTD activity is maximal at $37^{\circ} \mathrm{C}$ and $\mathrm{pH} 6.0$ [24] and, thus, all tests were run under these conditions. One unit of BTD activity is defined as the amount of protein required to release $1 \mathrm{nmol}$ of PABA $120 \mathrm{~min}^{-1}$ under the conditions of the assay.

\subsection{Enzyme kinetics}

$K_{\mathrm{m}}, V_{\max }$, and $K_{\mathrm{i}}$ [29] were determined as follows. The concentration of inhibitors was kept constant $(0.5 \mathrm{mM})$ in enzyme assays as described above, while the concentration of the substrate $N-(+)$-biotinyl-PABA was varied from 0.05 to $1 \mathrm{mM}$. The enzyme kinetics module of Sigmaplot 10.0 was used for calculations [30].

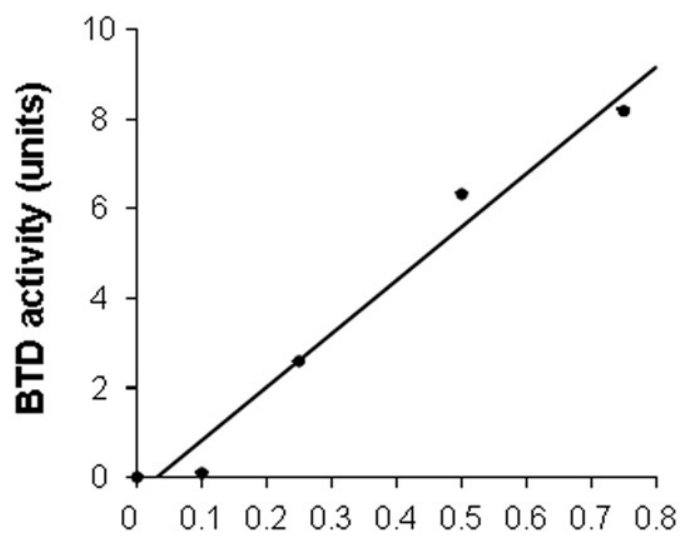

N-(+)-biotinyl-PABA (mM)

Fig. 2. BTD activity depends on the concentration of its substrate, $N-(+)-$ biotinyl-4-amidobenzoic acid. BTD activity was monitored by the release of PABA from $N-(+)$-biotinyl-PABA. The S.D.'s are too small to be visible $(y=0.11 x-1.19 ; r=.989)$. 


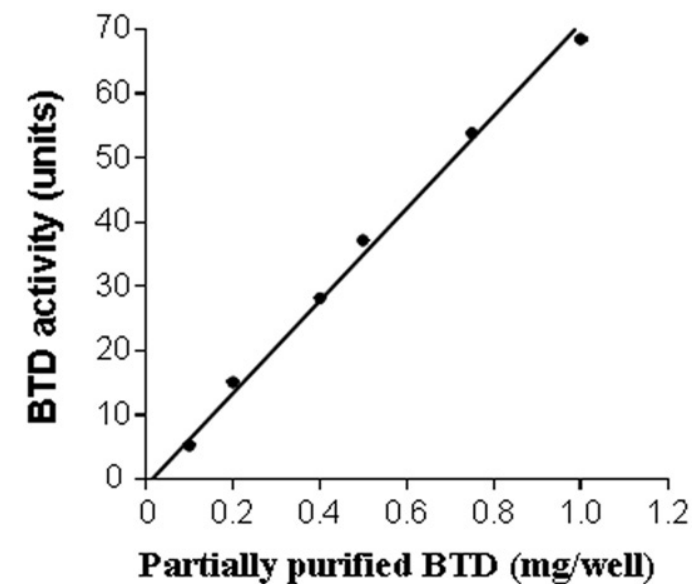

Fig. 3. Hydrolysis of $N$-(+)-biotinyl-4-amidobenzoic acid $(60 \mathrm{nmol} / \mathrm{well})$ depends on the amount of partially purified BTD. The S.D.'s are too small to be visible $(y=0.072 x-1.03 ; r=.997)$.

\subsection{Biotin transport}

Theoretically, the biotin analogs tested here might affect both biotin transport into human cells and BTD activity. Here, biotin transport was quantified using a physiological concentration of $\left[{ }^{3} \mathrm{H}\right]$ biotin $(475 \mathrm{pM})$ in the presence or absence of putative BTD inhibitors $(0.5 \mathrm{mM})$ as described [31]; the $K_{\mathrm{m}}$ of biotin transporters is in the low micromolar range [32]. Human Jurkat cells were used for biotin transport studies [33].

\subsection{Statistical analysis}

Heterogeneous variances were identified by using Bartlett's test, and data were log transformed where applicable [34]. Significance of differences was tested by one-way ANOVA. Fisher's protected least significant difference procedure was used for post hoc testing. StatView 5.0.1 (SAS Institute, Cary, NC) was used to perform all

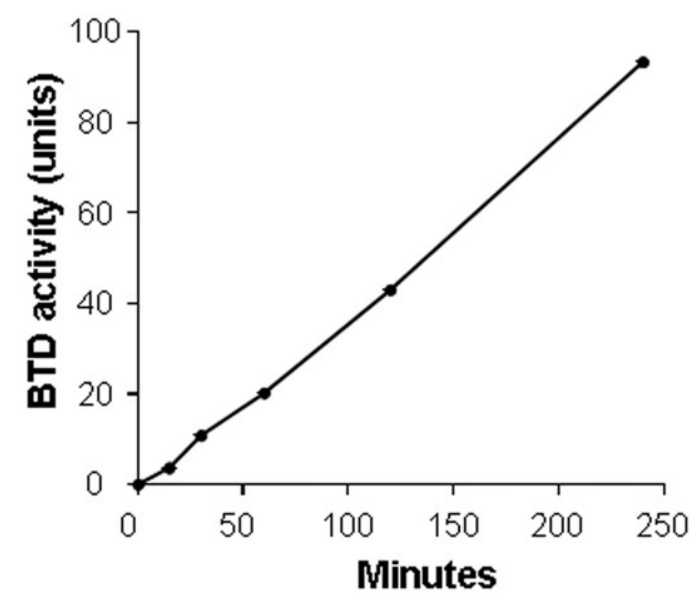

Fig. 4. Hydrolysis of $N$-(+)-biotinyl-4-amidobenzoic acid by partially purified BTD is linear for up to $4 \mathrm{~h}$. Values are means \pm S.D. $(n=6)$. The $\mathrm{S}$. D.'s are too small to be visible.

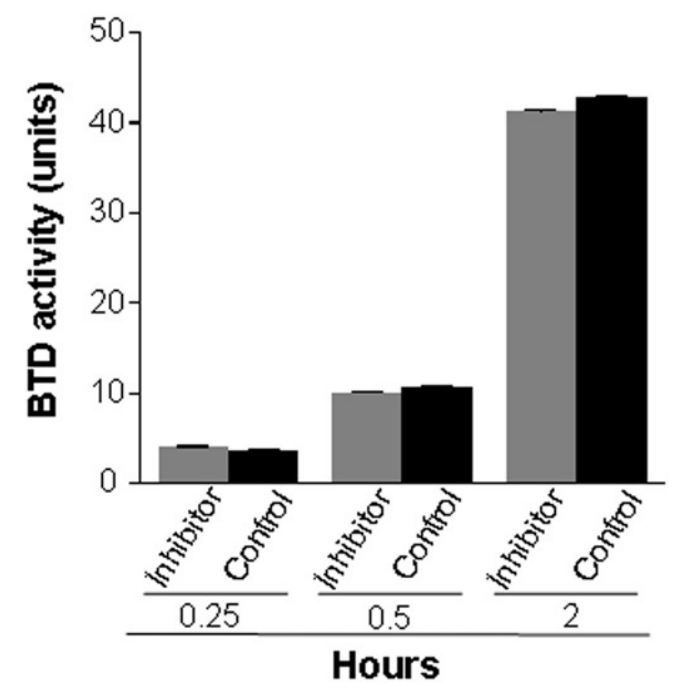

Fig. 5. Biotinyl 2,4,6-trimethylbenzenamide (1 mM) does not inhibit BTD. The effects of the treatment are not significantly different compared with inhibitor-free controls. The incubation times denote the hour of incubation of partially purified BTD, substrate and inhibitor. Values are means \pm S.D. $(n=6$; $P>05)$.

calculations. Differences were considered significant if $P<.05$. Data are expressed as mean $\pm \mathrm{SD}$.

\section{Results}

\subsection{Calibration and linearity of the BTD assay}

BTD activity was dependent on substrate concentration, enzyme abundance and time. First, known amounts (0$40 \mathrm{nmol}$ ) of synthetic PABA were used to generate a standard curve (Fig. 1). This assay was linear up to 40 nmol PABA.

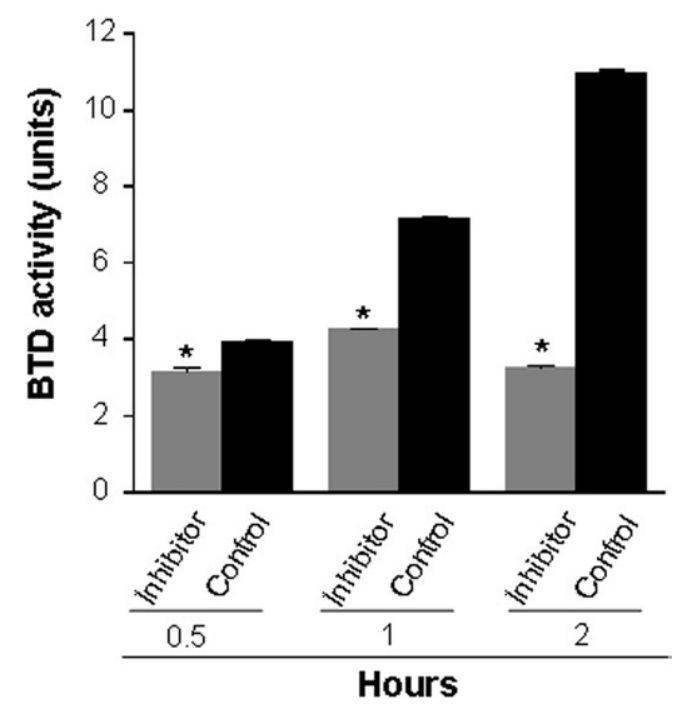

Fig. 6. Biotinyl-methyl 4-(amidomethyl)benzoate $(1 \mathrm{mM})$ inhibits BTD. Values are means \pm S.D. ( $n=6 ; * P<.05$ compared with inhibitor-free control). The incubation times denote the hour of incubation of partially purified BTD, substrate, and inhibitor. 


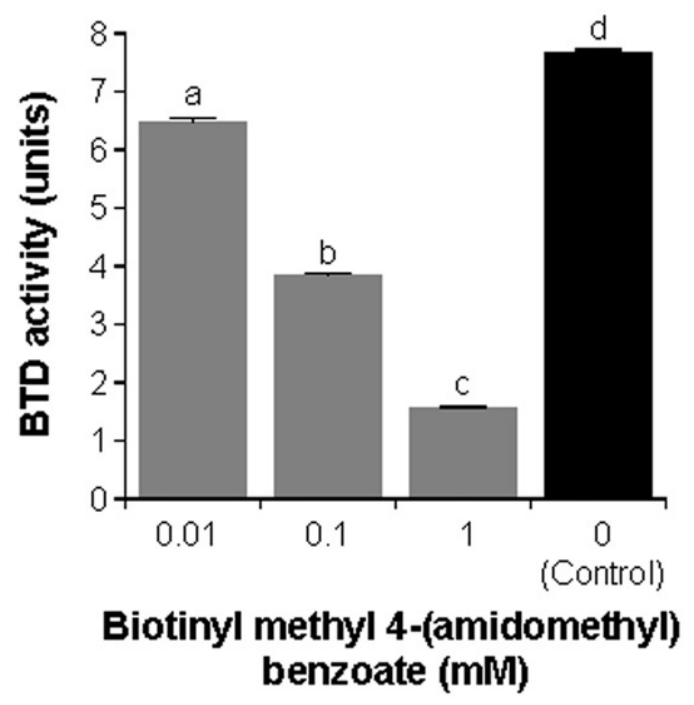

Fig. 7. Biotinyl-methyl 4-(amidomethyl)benzoate inhibits BTD activity in a concentration-dependent fashion. Values are means $\pm \mathrm{SD}(n=6) .{ }^{\mathrm{a}, \mathrm{b}, \mathrm{c}, \mathrm{d}}$ Bars not sharing the same letter are significantly different from the inhibitor-free control $(P<.05)$.

Second, dependence of BTD activity on substrate concentration was quantified by incubating BTD with 0 (control), $0.1,0.25,0.5$ and $0.75 \mathrm{mM}$ of $N$-(+)-biotinyl-PABA per well in a 96-well plate. PABA released from $N-(+)$-biotinylPABA reached a plateau at $0.5 \mathrm{mM}$ of $\mathrm{N}-(+)$-biotinyl-PABA per well as judged by absorbance at $546 \mathrm{~nm}$ (Fig. 2); all subsequent reactions were carried out using $0.5 \mathrm{mM}$ of $\mathrm{N}$-(+)-biotinyl-PABA per well. Third, partially purified BTD from plasma was added in increasing concentration: $0,0.1$, $0.2,0.4,0.5,0.75$ and $1 \mathrm{mg}$ of protein per well. The assay was linear up to a concentration of $1 \mathrm{mg}$ of partially purified BTD per well (Fig. 3). Fourth, a time course was conducted to determine whether the hydrolysis of $N$-(+)-biotinyl-PABA was linear with time. BTD and $N-(+)$-biotinyl-PABA were incubated in assay buffer for up to $4 \mathrm{~h}$ after the addition of $0.5 \mathrm{mM}$ of $N$-(+)-biotinyl-PABA at $37^{\circ} \mathrm{C}$. The hydrolysis of $\mathrm{N}$-(+)-biotinyl-PABA was linear up to $4 \mathrm{~h}$ (Fig. 4); all subsequent incubations with BTD were carried out for $2 \mathrm{~h}$ following the addition of $60 \mathrm{nmol}(0.5 \mathrm{mM}$ final concentration/well) $N$-(+)-biotinyl-PABA unless otherwise noted.

Table 2

Kinetics of BTD inhibitors

\begin{tabular}{|c|c|c|c|}
\hline \multirow[t]{2}{*}{ Inhibitor name } & \multicolumn{3}{|l|}{ Kinetic variables } \\
\hline & 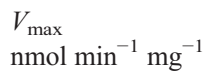 & $\begin{array}{l}K_{\mathrm{m}} \\
\mathrm{mM}\end{array}$ & $\begin{array}{l}\mathrm{K}_{\mathrm{i}} \\
\mathrm{mM}\end{array}$ \\
\hline $\begin{array}{l}\text { Biotinyl methyl } \\
\text { 4-(amidomethyl)benzoate }\end{array}$ & $0.29 \pm 0.001$ & $0.04 \pm 0.0004$ & $0.06 \pm 0.008$ \\
\hline Biotinyl anilide & $0.26 \pm 0.006$ & $0.07 \pm 0.048$ & $0.26 \pm 0.183$ \\
\hline Biotinyl 2-amido-pyridine & $0.28 \pm 0.002$ & $0.01 \pm 0.003$ & $0.27 \pm 0.011$ \\
\hline Biotinyl allylamide & $0.35 \pm 0.008$ & $0.06 \pm .002$ & $0.09 \pm 0.011$ \\
\hline
\end{tabular}

Data are means \pm S.D.

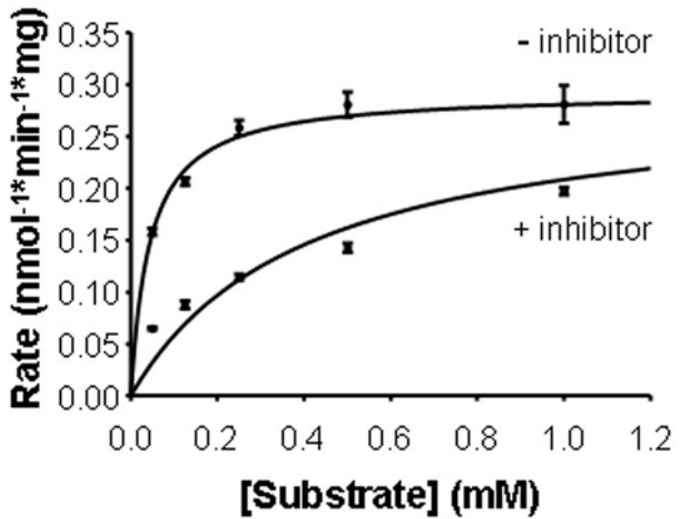

Fig. 8. BTD activity is reduced in a substrate-concentration dependent manner in the presence or absence of $0.5 \mathrm{mM}$ of the inhibitor biotinylmethyl 4-(amidomethyl)benzoate.

\subsection{Inhibitors of $B T D$}

Seven of the 13 compounds tested here inhibited BTD. In contrast, the following compounds did not significantly affect BTD activity and were used as negative controls in selected experiments: biotinyl diphenylamide, biotinyl dibenzylamide, biotinyl (R)-1-(1-naphthyl)ethylamide, biotinyl 2,4,6-trimethylbenzenamide, biotinyl 3,4-dimethanilide and biotinyl 4-amidobenzonitrile. These compounds had no meaningful effects on BTD activity even if concentrations as high as $0.5 \mathrm{mM}$ were tested. The compounds tested here are all biotin analogs, and it is highly unlikely that concentrations greater than $0.5 \mathrm{mM}$ can be achieved in biological fluids in vivo [35]. Fig. 5 depicts compound biotinyl 2,4,6trimethylbenzenamide as a representative example.

In contrast, the following compounds inhibited BTD activity by more than $25 \%$ : biotinyl anilide, biotinyl allylamide, biotinyl $\mathrm{N}$-methylanilide, biotinyl-methyl 4-(amidomethyl)benzoate, biotinyl 2-amido-pyridine, biotinyl

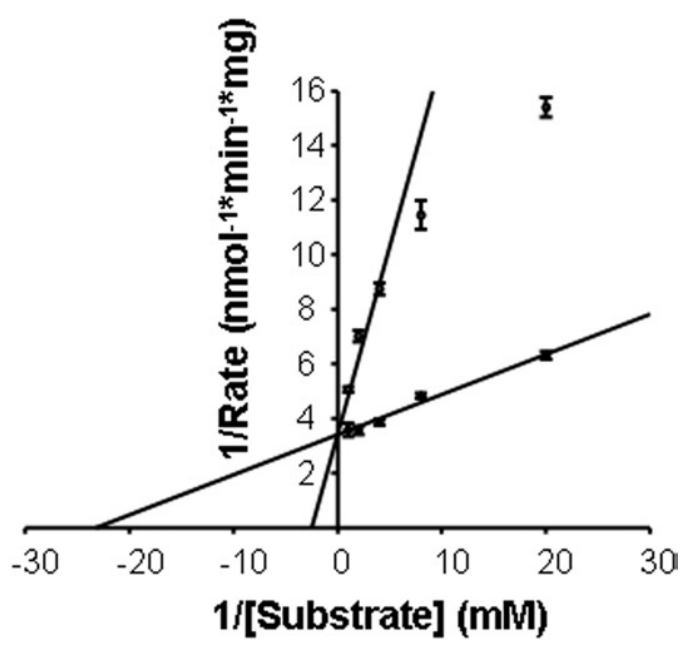

Fig. 9. Lineweaver-Burk plot demonstrating competitive inhibition of BTD by biotinyl methyl 4-(amidomethyl)benzoate. $V_{\max }=0.29 \pm 0.009 \mathrm{nmol}$ $\min ^{-1} \mathrm{mg}^{-1} ; K_{\mathrm{m}}=0.04 \pm 0.007 \mathrm{mM} ; K_{\mathrm{i}}=0.06 \pm 0.01 \mathrm{mM} ; n=3$. 
4-amidophenylboronic acid and biotinyl benzylamide. Biotinyl-methyl 4-(amidomethyl)benzoate was the most effective compound of all the inhibitors tested (Fig. 6). For example, if BTD was incubated with $N$-(+)-biotinyl-PABA in the presence of biotinyl methyl 4-(amidomethyl)benzoate for 30, 60 and $120 \mathrm{~min}$, the hydrolysis of $\mathrm{N}$-(+)-biotinyl-PABA was $80 \%$, $59 \%$ and $30 \%$, respectively, of inhibitor-free controls containing only dimethyl sulfoxide (DMSO). A greater percent inhibition at earlier time points is an event frequently seen with competitive inhibitors [29]. Importantly, the percent inhibition of BTD increased if concentrations of inhibitors were increased, consistent with competitive inhibition of BTD by biotinyl methyl 4-(amidomethyl)benzoate (Fig. 7). For example, if BTD was incubated with $N$-(+)-biotinyl-PABA in the presence of $0.01,0.1$ and $1 \mathrm{mM}$ biotinyl methyl 4-(amidomethyl)benzoate, the inhibition of hydrolysis of $\mathrm{N}$-(+)-biotinyl-PABA was $16 \%, 50 \%$ and $80 \%$, respectively, compared to inhibitor-free controls containing only DMSO (Fig. 7).

Enzyme kinetics studies were conducted to confirm that the biotin analogs tested here decreased BTD activity by competitive inhibition. In these experiments we kept the concentrations of inhibitors constant $(0$ vs. $0.5 \mathrm{mM})$ and varied the concentrations of the substrate $N-(+)$-biotinylPABA $(0.05-1 \mathrm{mM})$. For all the inhibitors tested, the percent inhibition of BTD decreased if the concentration of $N-(+)-$ biotinyl-PABA was increased. $K_{\mathrm{m}}$ and $V_{\max }$ values were consistent competitive inhibition (Table 2). The $K_{\mathrm{i}}$ value for biotinyl methyl 4-(amidomethyl)benzoate was smaller than $K_{\mathrm{i}}$ for all the other inhibitors, suggesting that this compound has a greater affinity for BTD than the other compounds tested (Figs. 8 and 9).

Finally, we determined whether biotinyl methyl 4-(amidomethyl)benzoate affected cellular biotin transport, potentially producing artifacts in future studies of BTD-mediated chromatin biology at the cellular level. Biotin uptake into Jurkat cells was quantified in the presence of excess biotinyl methyl 4-(amidomethyl)benzoate, biotinyl anilide (specificity control) and DMSO (negative control). Biotinyl methyl 4-(amidomethyl)benzoate did not affect biotin uptake into Jurkat cells compared with DMSO controls ( $13 \pm 0.6$ vs. $13 \pm$ 0.9 amol $\times 5 \times 10^{-6}$ cells $\left.\times 30 \mathrm{~min}^{-1} ; P>.05 ; n=3\right)$, whereas biotinyl anilide caused a significant decrease of biotin uptake $\left(5.4 \pm 0.3 \mathrm{amol} \times 5 \times 10^{-6}\right.$ cells $\left.\times 30 \mathrm{~min}^{-1} ; P>.05 ; n=3\right)$.

\section{Discussion}

Previous studies of BTD depended on using timeconsuming cuvette-based assays [26-28], making highthroughput screening of BTD inhibitors a tedious task. Here, we present a 96-well plate assay that for the first time offers the means for high-throughput screening of BTD activity and putative BTD inhibitors.

Using this assay and an array of synthetic biotin derivatives, we succeeded in identifying seven putative
BTD inhibitors. The most efficient compound was biotinylmethyl 4-(amidomethyl)benzoate that inhibited BTD up to $80 \%$ at a concentration of $1 \mathrm{mM}$. Our kinetics studies suggest that biotinyl-methyl 4-(amidomethyl)benzoate (and other compounds tested here) act by reversible, competitive inhibition of BTD.

The inhibitors presented here are biotin derivatives and are likely to primarily affect proteins involved in biotin metabolism such as BTD, HCS and biotin transporters, as opposed to affecting enzyme activity globally. Unspecific inhibitors such as para-hydroxymercuribenzoate, hydroxylamine and mercaptoethanol do not offer the degree of specificity needed for cell biology studies [8]. For example, mercaptoethanol reduces sulfhydryl groups in enzymes, causing conformational changes that affect enzyme activity. Our studies on biotin transport provide evidence that some BTD inhibitors do not affect biotin uptake, suggesting specificity for BTD. We are currently in the process of investigating effects of BTD inhibitors on other histone biotinyl ligases such as HCS.

Note, however, that even if an inhibitor is specific for BTD, it will abolish biological functions of this enzyme to the same extent in various cell compartments. For example, loss of BTD activity may result in biological changes that could either be a result of decreased recycling of biotin from breakdown products of carboxylases in the cytoplasm [36] or of remodeling of chromatin through histone debiotinylation in the nucleus [2]. Our first-generation inhibitors of BTD do not overcome the problem of specifically targeting cytoplasmic vs. nuclear BTD. A second generation of BTD inhibitors is currently being developed in our laboratory. The goal of these ongoing studies is to create an inhibitor that specifically targets nuclear BTD. Also, we will seek to modify these secondgeneration inhibitors so that they do not undergo significant metabolism and loss of activity. Once these secondgeneration inhibitors become available, we hope to specifically characterize roles of BTD in chromatin remodeling.

\section{Acknowledgment}

This study was a contribution of the University of Nebraska Agricultural Research Division and was supported in part by funds provided through the Hatch Act. Additional support was provided by NIH Grants DK 063945 and ES 015206, USDA Grant 2006-35200-17138 and by NSF EPSCoR Grants EPS-0346476 and EPS-0701892.

\section{References}

[1] Narang MA, Dumas R, Ayer LM, Gravel RA. Reduced histone biotinylation in multiple carboxylase deficiency patients: a nuclear role for holocarboxylase synthetase. Hum Mol Genet 2004;13:15-23.

[2] Chew YC, Camporeale G, Kothapalli N, Sarath G, Zempleni J. Lysine residues in $\mathrm{N}$ - and $\mathrm{C}$-terminal regions of human histone $\mathrm{H} 2 \mathrm{~A}$ are targets for biotinylation by biotinidase. J Nutr Biochem 2006;17: 225-33. 
[3] Chiba Y, Suzuki Y, Aoki Y, Ishida Y, Narisawa K. Purification and properties of bovine liver holocarboxylase synthetase. Arch Biochem Biophys 1994;313:8-14.

[4] Pispa J. Animal biotinidase. Ann Med Exp Biol Fenniae 1965;43: 4-39.

[5] Wolf B, Grier RE, McVoy JRS, Heard GS. Biotinidase deficiency: a novel vitamin recycling defect. J Inherit Metab Dis 1985;8:53-8.

[6] Dakshinamurti K, Chauhan J. Biotin-binding proteins. In: Dakshinamurti K, editor. Vitamin receptors: vitamins as ligands in cell communication. Cambridge (UK): Cambridge University Press; 1994. p. 200-49.

[7] Wolf B, Heard GS. Biotinidase deficiency. In: Barness L, Oski F, editors. Advances in pediatrics. Chicago (Ill): Medical Book Publishers; 1991. p. 1-21.

[8] Hymes J, Fleischhauer K, Wolf B. Biotinylation of histones by human serum biotinidase: assessment of biotinyl-transferase activity in sera from normal individuals and children with biotinidase deficiency. Biochem Mol Med 1995;56:76-83.

[9] Hymes J, Wolf B. Human biotinidase isn't just for recycling biotin. J Nutr 1999;129:485S-9S.

[10] Stanley JS, Griffin JB, Zempleni J. Biotinylation of histones in human cells: effects of cell proliferation. Eur J Biochem 2001;268: 5424-9.

[11] Camporeale G, Shubert EE, Sarath G, Cerny R, Zempleni J. K8 and K12 are biotinylated in human histone H4. Eur J Biochem 2004;271: 2257-63.

[12] Fischle W, Wang Y, Allis CD. Histone and chromatin cross-talk. Curr Opin Cell Biol 2003;15:172-83.

[13] Jenuwein T, Allis CD. Translating the histone code. Science 2001;293: 1074-80.

[14] Kothapalli N, Sarath G, Zempleni J. Biotinylation of K12 in histone H4 decreases in response to DNA double strand breaks in human JAr choriocarcinoma cells. J Nutr 2005;135:2337-42.

[15] Camporeale G, Oommen AM, Griffin JB, Sarath G, Zempleni J. K12biotinylated histone $\mathrm{H} 4$ marks heterochromatin in human lymphoblastoma cells. J Nutr Biochem 2007;18:760-8.

[16] Camporeale G, Giordano E, Rendina R, Zempleni J, Eissenberg JC. Drosophila holocarboxylase synthetase is a chromosomal protein required for normal histone biotinylation, gene transcription patterns, lifespan and heat tolerance. J Nutr 2006;136:2735-42.

[17] Camporeale G, Zempleni J, Eissenberg JC. Susceptibility to heat stress and aberrant gene expression patterns in holocarboxylase synthetase-deficient Drosophila melanogaster are caused by decreased biotinylation of histones, not of carboxylases. J Nutr 2007;137:885-9.

[18] Ballard TD, Wolff J, Griffin JB, Stanley JS, Calcar SV, Zempleni J. Biotinidase catalyzes debiotinylation of histones. Eur J Nutr 2002;41: $78-84$.
[19] Zempleni J. Uptake, localization, and noncarboxylase roles of biotin. Annu Rev Nutr 2005;25:175-96.

[20] Stanley CM, Hymes J, Wolf B. Identification of alternatively spliced human biotinidase mRNAs and putative localization of endogenous biotinidase. Mol Genet Metab 2004;81:300-12.

[21] Cole H, Reynolds TR, Lockyer JM, Buck GA, Denson T, Spence JE, et al. Human serum biotinidase cDNA cloning, sequence, and characterization. J Biol Chem 1994;269:6566-70.

[22] Knight HC, Reynolds TR, Meyers GA, Pomponio RJ, Buck GA, Wolf B. Structure of the human biotinidase gene. Mamm Genome 1998;9:327-30.

[23] McMahon RJ. Biotin in metabolism and molecular biology. Annu Rev Nutr 2002;22:221-39.

[24] Chauhan J, Dakshinamurti K. Purification and characterization of human serum biotinidase. J Biol Chem 1986;261:4268-75.

[25] Wolf B, Grier RE, Allen RJ, Goodman SI, Kien CL. Biotinidase deficiency: An enzymatic defect in late-onset multiple carboxylase deficiency. Clin Chim Acta 1983;131:273-81.

[26] Knappe J, Brümmer W, Biederbick K. Reinigung und Eigenschaften der Biotinidase aus Schweinenieren und Lactobacillus Casei. Biochem Z 1963;338:599-613.

[27] Backman-Gullers B, Hannestad U, Nilsson L, Sörbo B. Studies on lipoamidase: characterization of the enzyme in human serum and breast milk. Clin Chim Acta 1990;191:49-60.

[28] Nilsson L, Ronge E. Lipoamidase and biotinidase deficiency: evidence that lipoamidase and biotinidase are the same enzyme in human serum. Eur J Clin Chem Clin Biochem 1992;30:119-26.

[29] Segel IR. Biochemical calculations. 2nd ed. New York: John Wiley and Sons, Inc; 1968. p. 430.

[30] Systat Software, Inc., Sigmaplot 10.0. www.systat.com; accessed April 11, 2007.

[31] Zempleni J, Mock DM. Uptake and metabolism of biotin by human peripheral blood mononuclear cells. Am J Physiol Cell Physiol 1998; 275:C382-8.

[32] Prasad PD, Wang H, Kekuda R, Fujita T, Fei Y-J, Devoe LD, et al. Cloning and functional expression of a cDNA encoding a mammalian sodium-dependent vitamin transporter mediating the uptake of pantothenate, biotin, and lipoate. J Biol Chem 1998;273:7501-6.

[33] Manthey KC, Griffin JB, Zempleni J. Biotin supply affects expression of biotin transporters, biotinylation of carboxylases, and metabolism of interleukin-2 in Jurkat cells. J Nutr 2002;132:887-92.

[34] SAS Institute, (1999) StatView reference SAS Publishing, StatView Reference.

[35] Mock DM, Lankford GL, Mock NI. Biotin accounts for only half of the total avidin-binding substances in human serum. J Nutr 1995;125: 941-6.

[36] Wolf B, Heard GS, McVoy JRS, Grier RE. Biotinidase deficiency. Ann NY Acad Sci 1985;447:252-62. 